\title{
Exploring the Role of Internet Usagein Facilitating Marketing Activities:An Empirical Study of UK Companies
}

\author{
Riyad Eid \\ BSc (Hons) MSc PGDip PhD MCIM \\ Faculty of Business and Economics \\ United Arab Emirates University \\ Al-Ain- UAE \\ E-mail: mailto:riyad.eid@wlv.ac.ukRiyad.Aly@uaeu.ac.ae
}

\author{
Yasser El-Kassrawy \\ BSc (Hons) MSc PGDip PhD \\ Faculty of Commerce \\ Tanta University \\ Tanta-Egypt \\ E-mail: yaelkassrawy@gmail.com
}




\title{
Exploring the Role of Internet Usagein Facilitating Marketing Activities:An Empirical Study of UK Companies
}

\author{
Riyad Eid \\ BSc (Hons) MSc PGDip PhD MCIM \\ Faculty of Business and Economics \\ United Arab Emirates University \\ Al-Ain- UAE \\ E-mail: mailto:riyad.eid@wlv.ac.ukRiyad.Aly@uaeu.ac.ae \\ Yasser El-Kassrawy \\ BSc (Hons) MSc PGDip PhD \\ Faculty of Commerce \\ Tanta University \\ Tanta-Egypt \\ E-mail: yaelkassrawy@gmail.com
}

The purpose of this research is to investigate the effects of the Internet use on marketing activities. Based on the previous literature, the effect of the Internet on marketing activities has been categorised into four basic dimensions, 1) customer relations' activities, 2) marketing performance, 3) marketing efficiency 4) customer targeting activities. However, few empirical studies have been done regarding customer relations and targeting activities that are affected by the use of the Internet, and the effect of that on marketing efficiency. By studying the practice of 123 UK companies, it has been found that the use of the Internet positively influences customer relations and targeting activities, marketing performanceand marketing efficiency.

\section{INTRODUCTION}

The use of the Internet for business transactions is wide spread. For example, computer-manufacturing companies such as IBM, Xerox, Motorola, Intel, Sun, Hewlet Packard and Digital Equipment are beginning to use the Internet to link remote sites, business partners and customers for collaborative development, software support and distribution, and communications (Paul, 1996). In the retail industry, America's largest TV-shopping firm, Home shopping network, has bought the Internet Shopping Network to consolidate its position and market share. In the pharmaceutical industry, Du Pont 
Marck Pharmaceuticals Co., in Rahway, New Jersey, uses the a public medical database to explore new areas of marketing research in the treatment of central nervous technological system disorders. Du Pont has shortened the development cycle by facilitating collaborative research among experts and by using the technological systems by scanning hundreds of reports to bring new drugs more quickly to the market (Soh et al., 1997:217). In a similar vein, in the aerospace industry, the Internet enables Boeing to share design tools and facilitate the coordination among engineers, customers, maintenance people, project managers and component suppliers across the globe. Using the Internet, Boeing's customers no longer need to wait 3 years to place an order. Boeing has become able to deliver a plane in 8-12 months and to build 620 aeroplanes annually, up from 228 in 1992.

The penetration of IT in many aspects of society in general and in business organization in particular could be attributed to many reasons. First, emerging current trends in the market environment, such as shrinkage of markets, increase of competition, technology turbulence, and diffusion of IT through mainoperations of the organisation. These trends call for increased outsourcing activities, transformations and re-structuring in the value chains of the organisation and their distribution channels, and the formation of new network inter-organisational structures. In fact, these trends are calling for enhanced communication capabilities and increased inter-organisational exchanges (Eid and Trueman, 2004; Even et al., 2010).

Second, the Internet offers an array of benefits for marketers. In that sense, Evans and King (1999) defined some of these benefits as: multiple marketing usage, access to commercial research, competitive intelligence, customer service, just in time inventory 
planning, sales channels, support for channel partners, image enhancement, rabid growth, global reach, around the clock presence, ability to normally target marketing efforts, cost effectiveness, up to minute information, and multimedia vehicle. These benefits are achieved through several techniques in which the Internet facilitates, transformsand restructure the marketing functions. These techniques are disintermediation, customer relations management, mass customisation, sales force automation, and collaboration and coordination (Eid and Trueman, 2004; Even et al., 2010;Kalakota and Whinston, 1997; Papows, 1998; Peppers and Rogers, 1999; Rose et al., 2011; Venkatraman and Henderson, 1998). Disintermediation; the web enables marketers to uncover new ways to eliminate process redundancies and establish direct interface with customers, suppliers, and strategic alliance partners, thus reducing transaction cost significantly (Papows, 1998). Customer relations management, the speed interactivity, continuity, and customisation capabilities of the Internet enable marketers to manage customers as a strategic asset. Customer service and support functions can be significantly strengthened. Web sites and e-mail systems are being used to answer customers' queries about products, availability, upgrades, and repairs as well as to show customers new products and gather their ideas.

Mass customisation; the internet and e-mail system provide marketers extraordinary capabilities to target specific groups or individuals precisely and enable them to practice mass customisation and one to one marketing strategies by adapting communications and other elements of the marketing mix to customer segments of size one (Peppers and Rogers, 1999). Sales force automation; the Internet and the Web can play an important role in enhancing the productivity and effectiveness of the sales force 
by facilitating the selective automation of processes related to supporting the field sales force and integrating sales activity into a company's information structure, (Kalakota and Whinston, 1997). Collaboration and Coordination; the Internet provides a universal connectivity in synchronous and asynchronous modes that facilitates intra- and interorganisational coordination on an unprecedented scale (Even et al., 2010; Venkatraman and Henderson, 1998). On the other hand, Soh et al. (1997:217) found that businesses use the Internet for marketing and advertising; customer services and support; information gathering, and, to lesser degree, electronic transactions.

\subsection{Research Problem}

Despite the great growth of the Internet use in most developed and developing countries, its utilization still not efficient enough. Moreover, systematic research in this field is still scarce and blurred concerning the impact of using the Internet on marketing activities. Most of the recent literature have done in an exploratory manner, yet only a handful have made an attempt to study the effect of the Internet on marketing activities such as customer targeting activities, customer relations activities, marketing performance and marketing efficiency (Avolonitis and Karayanni, 2000; Clarke and Flaherty 2003; Eid and El-Gohary, 2013; Karayanni and Baltas 2003; Rose et al., 2011). Therefore, this paper is an attempt to determine the effect of Internet usage on marketing activities. Factors examined include the following: 1) customer relations' activities, 2) marketing performance, 3) marketing efficiency 4) customer targeting activities. 


\subsection{Research Objective}

The present paper pursues the following objectives:

- To identify the marketing activities that are affected by the Internet use and,

- To specify and test hypothesized relationships derived from the literature review.

To achieve its objective, this research is structured as follow: having had the introductory section, section two and three provide the development of the literature review and the hypotheses of the study are presented respectively. Next, the methodology of the study is discussed in section including the analysis,hypotheses testing and results. Some discussion, conclusion and implications are provided in last two sections.

\section{REVIEW OF LITERATURE}

The purpose of this research is to investigate the effects of the Internet use on marketing activities. Consequently, based on the previous literature, the effect of the Internet on marketing activities has been categorised into four basic dimensions, 1) customer relations' activities, 2) marketing performance, 3) marketing efficiency 4) customer targeting activities. The four dimensions are discussed below. Before providing some literature related to these dimensions, we illustrate some understanding to the Internet use in marketing.

\subsection{Internet Usage for Marketing Purposes}

There has been considerable research into the use of the Internet for marketing communication and commerce in recent years (Eid and Elgohary, 2013). The need to understand how and why industrial companies utilize the Internet is important for 
researchers and practitioners alike so that they can understand and control the dynamics of application for different purposes. Consequently, this study makes a comprehensive review of information technology, information systems, and marketing literature to locate items that can predict and control Internet use in marketing activities.

A few recent studies have investigated factors affecting the use of the Internet and WWW (Cheung et al., 2000; Fenech, 1998; Gefen and Straub, 1997; Eid and El-Gohary, 2013; Lederer et al., 2000; Lin and Lu, 2000; Moon and Kim, 2001). Chan and Swatman (2000:72) stated that there is very little literature that discusses the process of Internetbased marketing, so that researchers must start with the literature concerning more general IT/IS implementation and hope to develop a body of theory, which is more explicitly focused on the area of Internet marketing.

However, in this study the use of Internet usage is examined following Avlonitis and Karayanni (2000) who deal with it as a second order construct that consist of seven items. Internet use includes the use of any Internet-based applications for conducting company marketing activities. As a result, Internet usage includes Internet Marketing, EMail marketing, Intranet Marketing, Extranet Marketing, Mobile Marketing, Tele Marketing, Electronic Data Interchange (EDI) for marketing activities, customer relationship management $(\mathrm{CRM})$ and more. However, this research, and based on the results of reviewing the relevant literature, focuses on Internet marketing, E-Mail marketing, Intranet Marketing, Extranet Marketing and Mobile Marketing (Evans \& King, 1999; Hofacker, 2001; Eid and El-Gohary, 2013; Eid \& Trueman, 2004; Chaffey et al., 2006). 


\subsection{Customer Relations Activities}

These activities can be encapsulated in sales management that includes customer classification and market segmentation, selling, service, and relation of existing customers. These activities seem to be very crucial for industrial marketers (Webster, 1984). This research focuses on sales activities that may be improved by using the Internet. For example, market segmentation, customer classification, management of customer database, and electronic transmission of advertisement material (i.e., electronic catalogues) to the customer (Avlonitis and Karayanni, 2000; Furnell and Karweni, 1999;

Lancioni et al., 2000; Rose et al., 2011).

\subsection{Marketing Performance}

Marketing performance is evaluated not only in the basis of sales, but also on other criteria that are essential to marketing. Bondra and Davis (1996) stated that the measures of IT (i.e., the Internet) performance should be closely linked to the objectives that were to be achieved through the applications by the marketing management. In empirical research sales, cooperation, return on assets and investments, service to customers, profits, market share, customer satisfaction, and outcomes given comparison levels have all been used either separately or in ad hoc combinations in the assessment of marketing performance (Anderson and Narus, 1990; Rose et al., 2011). However, the Internet is an out-directed IT that can be used both as a direct sales channel and as an interactive communication tool (i.e., sales force and marketing tool). Thus, it may affect sales performance in two ways: -

- Through achieving direct sales (i.e., via the WWW); and

- Indirectly, through enhancing interorganisational relationships, providing higher levels of productivity. 
However, the Internet creates the potential to interact with customers on a global scale.

This interaction may, in turn, allow marketers to target their customers on a one-to-one base basis and to build brand loyal relationships (Arnott and Bridgewater, 2002:87). Thus, this research focuses on performance issues that relates to marketing productivity such as sales, new orders, better service quality, superior customer relationships, new service development and adaptability to customer needs (Avlonitis and Karayanni, 2000; Mang and stauss, 1999; Poon and Swatman, 1998).

\subsection{Marketing Efficiency}

The Internet has been characterised as a tool for facilitating sales force efforts, thus leading to higher level of marketing efficiency (Anderson, 1996). Marketing efficiency resulted from cost reduction resulted through the use of the Internet in carrying out marketing activities, for example, reduction in cost of sales, customer service costs, time of routine service jobs, sales people travel time, and number of marketing people employed (Avlonitis and Karayanni, 2000; Borders et al., 2001; Chan and Swatman, 2000; Furnell and Karweni, 1999; Honeycutt et al., 1998; Lancioni et al., 2000; Lord, 2001; Lynn et al., 2002; Osterle et al., 2001; Rose et al., 2011). Osterle stated that the main benefits to be gained from implementing the Internet solution are as follow (Osterle et al., 2001:127).

- Efficiency of information processes for the customer. The convergence of information in the Internet (see enables customers to obtain all relevant information on existing and new products (price, technical descriptions, sales conditions, and interchangeability) via one channel. Since the site is maintained centrally, the company can easily assure that the information is up to date and benefit from cost savings in producing and distributing catalogues, price lists, and technical documents.

- Improved customer service level. Additionally, previously unavailable, features have been introduced with the Internet and will yield significantly higher services levels. Such as technical documents download and electronic order tracking. 
- Order processing efficiency. With the Internet, order-processing efficiency has increased remarkably. This has been mainly due to the homogenisation of master data, which reduces matching efforts and, consequently, eliminates misunderstandings as well.

\subsection{Customer Targeting Activities}

The Internet is becoming an essential tool in customer targeting activities marketing. Its use has revolutionised the dynamics of commerce and, like the telephone and fax machine, may be a major democratic force since it allows companies of different sizes to compete. Advantages have been cited by researcher such as low set-up cost, globalness, ease of entry, time independence, interactivity (Bennett and Roger, 1997).Others see better information management, better integration of suppliers and vendors, better channel partnership, lower transaction cost, better market understanding, expanded geographical coverage (Damanpour, 2001). Opportunities exist for improved communication, corporate logistics, competitive advantages, collaboration, information reach and retrieval, marketing and sale promotion, data transmission, globalisation (Ellsworth and Ellsworth, 1995,1996). Furthermore, this technology is linked to more rapid internationalisation, reduced importance of scale economies, reduced importance of global advertising cost as a barrier to entry, price standardisation, reduced importance of traditional intermediaries, electronic support for interfirm networks, new world wide marketing research medium (Even et al., 2010; Quelch and Klein, 1996).

There is also the possibility of simplifying the operational issues of doing business in other countries, reducing the dependence on agents and distributors, providing access to low cost or no cost market research, monitoring the on line efforts of 
competitors' product offerings and pricing, improving the feedback that comes directly from global market, enabling firms to reach a larger audience at a relatively low cost.

\section{RESEARCH HYPOTHESES}

\subsection{The relationship between the Internet Use andCustomer Relations Activities}

Undoubtedly, technology commercialization (TC) is an important driver of a firm's marketing success (Ho et al., 2011). The opportunities presented by the Internet use for marketing activities are considered as the Internet is now playing a vital role in the conducting of marketing activities due to its unique characteristics both as a market and as a medium. A web site or a web page can have the potential to directly reach a large number of markets in a fast and economical way. With relatively low investments almost any person who can read and write can have access to the World Wide Web. The Internet provides companies with the opportunity of developing successful economic businesses in ways that have never been available to them before. It puts these entrepreneurs in touch with previously unavailable global resources and opportunities so that they can communicate and conduct business with new and existing customers in an integrated and easy way.

Figure 1 depicts the research model and illustrates the propositions tested in this study.Customer relations activities that might be influenced by the use of the Internet include faster discovery of consumer needs, greater customisation of the products to customer needs, and faster new product testing (Avlonitis and Karayanni, 2000; Borders et al., 2001; Ellsworth and Ellsworth 1995,1996; Honeycutt et al., 1998; Lancioni, 2000; Lord, 2001; Poon and Swatman, 1998). Other activities that might be improved by using 
the Internet are market segmentation, customer classification, management of customer database, and electronic transmission of advertisement material (i.e., electronic catalogues) to the customer (Avlonitis and Karayanni, 2000; Furnell and Karweni, 1999; Lancioni et al., 2000). Thus, the following hypothesis is proposed:

H1:Internet use for marketing purposes has a significant positive impact on customer relations' activities.

\subsection{The relationship between the Internet Use andMarketing Performance}

Marketing performance is evaluated not only in the basis of sales, but also on other criteria that are essential to marketing such as improvement of customer relationships. Therefore, this study focuses on performance issues that relates to marketing productivity such as sales, new orders, and customer services and relationships (Avlonitis and Karayanni, 2000; Poon and Swatman, 1998). To see the role of the Internet in marketing performance the following hypothesis is proposed:

H2: Internet use for marketing purposes has a significant positive impact marketing performance.

\subsection{The relationship between the Internet Use andMarketing Efficiency}

The Internet has been characterised as a tool for facilitating marketing efforts, thus leading to higher level of marketing efficiency (Anderson, 1996). Many efficiency issues have been cited in the literature as a result of using the Internet for marketing purposes. These include for example, reduction in cost of sales, customer service costs, time of routine service jobs, sales people travel time, and number of marketing people employed (Avlonitis and Karayanni, 2000; Borders et al., 2001; Chan and Swatman, 2000; Even et al., 2010; Furnell and Karweni, 1999; Honeycutt et al., 1998; Lancioni et 
al., 2000; Lord, 2001; Lynn et al., 2002; Osterle et al., 2001). To see the role of the Internet in marketing efficiency the following hypothesis is proposed:

H3: Internet use for marketing purposes has a significant positive impact on marketing efficiency.

\subsection{The relationship between the Internet Use andCustomer Targeting Activities}

A number of authors have paid attention to the consequences of the Internet on customer targeting activities(Chaffey et al., 2000; Chan and Swatman, 2000; Duggan and Deveney, 2000; Hamill, 1997; Hamill and Gregory, 1997; Herbig and Hale, 1997; Hofacker, 2001; Kotab and Helsen, 2000; Quelch and Klien, 1996). These consequences include; good awareness, help in market selection, orientation to foreign customers, fast communication and documentation procedures, finding the right overseas agent and effective marketing mix policy. Therefore the following hypothesis is proposed:

H4:Internet use for marketing purposes has a significant positive impact on customer targeting activities. 


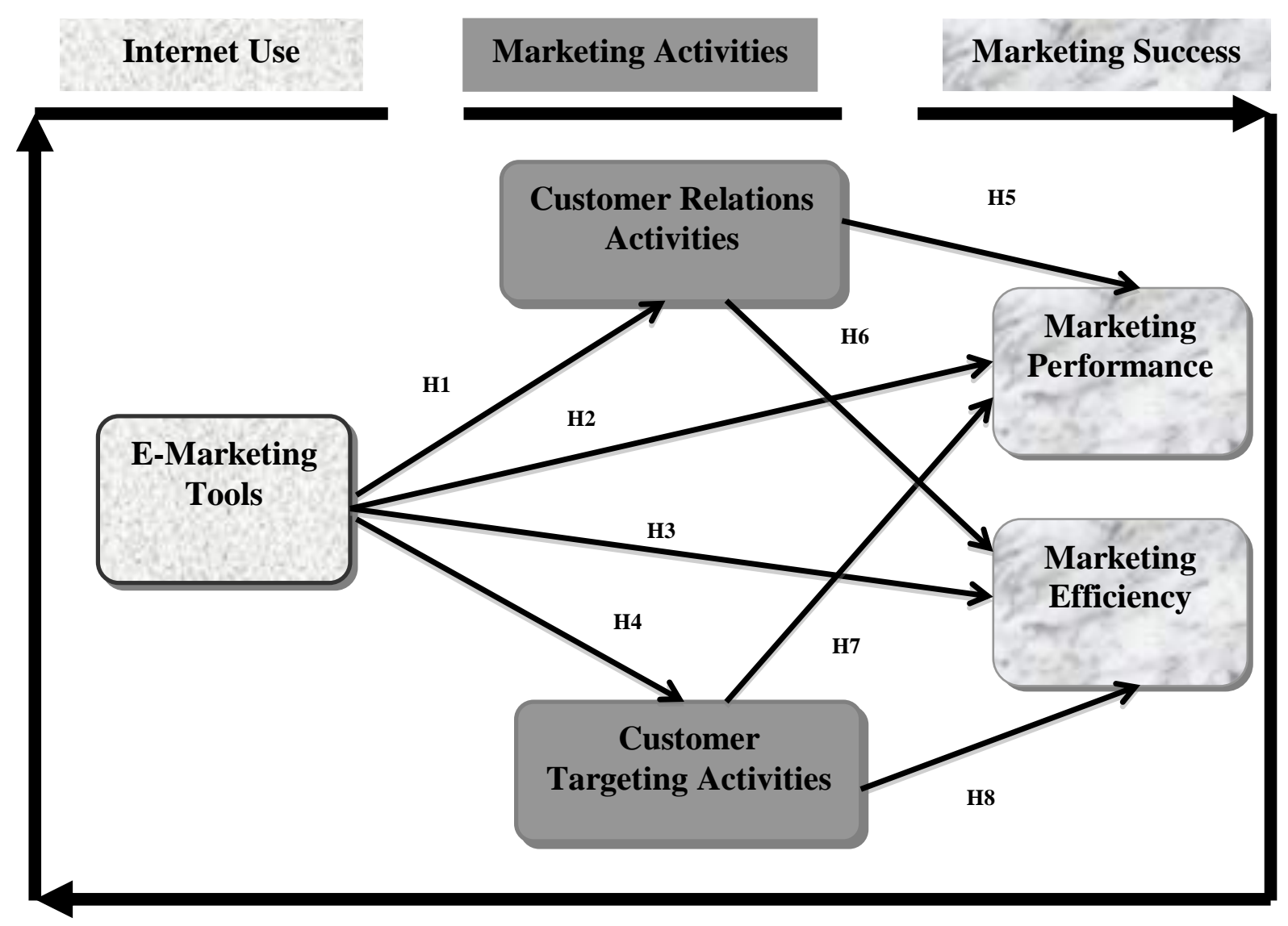

Figure 1: Research Model

As we are developing a structural model, the following hypothesesare suggested so as to test the indirect effect of the Internet use on marketing performance and marketing efficiency:

H5: Customer relations' activities have a significant positive impact on the marketing performance.

H6: Customer relations' activities have a significant positive impact on the marketing efficiency.

H7: Customer targeting activities have a significant positive impact on the marketing performance.

H8: Customer targeting activities have a significant positive impact on the marketing efficiency. 


\section{RESEARCH METHODOLOGY}

\subsection{Data collection}

The generalizablity of the study relied on the representativeness of the respondents. Therefore, a representative selection of companies was made from a database of companies that use the Internet for their marketing activities. The selection included companies from different industries. All the selected companies had implemented the Internet marketing system at least 5 year ago. A research packet, which contained a covering letter and an anonymous [self-administering] questionnaire, was mailed to the head of marketing departments; customer services officers or customer relationship managers [250 in total]. This procedure resulted in 128 questionnaires (including 5 unusable questionnaires, usable questionnaire $=123$ ). The response rate was calculated using the method proposed by De Vaus (1991: 99) and was $58.98 \%$.

The sample can be described as follows: a majority of the respondents were involved on Internet marketing implementation [78.00\%], most were younger than 40 years old [52\%], and a few respondent [approximately $2.4 \%$ ] were more than 50 years old. With respect to years of working with the Internet, approximately $25 \%$ of the sample had used Internet marketing for less than 5 years, and $61 \%$ had used it between 5 and 10 years. In terms of industry type $(6.5 \%)$ of the respondents were from the aerospace industry, 11.4 were members of the agriculture industry, (6.5) were Chemical and Allied Products companies, (32.5\%) were from the computer companies, (33.5) were industrial supplies companies and $(9.8 \%)$ were textile companies. Finally, more than half of the respondents hold the position of marketing managers in their companies $(55.3 .8 \%)$. On 
the other hand, $26 \%$ hold the position of sales manager, $9.8 \%$ hold the position of export manger and $9.8 \%$ are IT manager.

To ensure that the valid responses were representatives of the larger population, a non-response bias test was used to compare the early and late respondents. $\chi^{2}$ tests show no significant difference between the two groups of respondents at the $5 \%$ significance level, implying that a non-response bias is not a concern.

\subsection{Research instrument development-Measures}

The development of the research instrument was based mainly on new scales, because we could not identify any past studies directly addressing all of the issues in this research. However, and where possible, we used validated measures that have been previously applied. The constructs, scale items and factor loadings obtained from exploratory factor analysis are presented on the data analysis section. Two consecutive rounds of pre-testing were conducted in order to insure that respondents could understand the measurement scales used in the study: First, the questionnaire was reviewed by three academic researchers experienced in questionnaire design and next, the questionnaire was piloted with two Internet marketing experts known to the researcher. The pilot took the form of an interview where the participants were first handed a copy of the questionnaire and asked to complete it and then discuss any comments or questions they had. The outcome of the pre-testing process was a slight modification and alteration of the existing scales, in light of the scales context under investigation. 


\subsection{Analysis and Results}

First, the psychometric properties of the constructs were assessed by calculating the Cronbach's alpha reliability coefficient and the items-to-total correlation (Nunnally \& Bernstein, 1994). These coefficients are represented for each of the constructs in (Table I). All scales have reliability coefficients ranging from 0.8809 to 0.9306 , which exceed the cut-off level of 0.60 set for basic research (Nunally, 1978).

Table I: Measure of constructs' reliability

\begin{tabular}{|l|c|c|}
\hline Constructs & $\begin{array}{c}\text { Number } \\
\text { of Items }\end{array}$ & Alpha \\
\hline Customer Relations Activities & 6 & $\mathbf{. 8 8 0 9}$ \\
\hline Customer Targeting Activities & 7 & $\mathbf{. 9 3 0 6}$ \\
\hline Marketing Performance & 4 & $\mathbf{. 9 2 2 8}$ \\
\hline Marketing Efficiency & 4 & $\mathbf{. 9 1 4 2}$ \\
\hline Internet Use for Marketing Purposes & 7 & $\mathbf{. 8 7 5 4}$ \\
\hline
\end{tabular}

Second, we performed an exploratory factor analysis [with Varimax rotation] to examine if the items for a construct share a single underlying factor [i.e. are unidimensional]. Items, which did not satisfy the following two criteria, were deleted: [1] dominate loadings greater than 0.5, and [2] cross-loadings less than 0.35 (Hair et al., 1998).

Table II: Results of factor analysis

\begin{tabular}{|l|c|c|c|c|}
\hline \multicolumn{1}{|c|}{ No } & \multicolumn{4}{c|}{ Component } \\
\hline & Factor 1 & Factor 2 & Factor 3 & Factor 4 \\
\hline Customer needs discovery & 0.701 & & & \\
\hline Customisation & 0.682 & & & \\
\hline New product testing & 0.577 & & & \\
\hline Market segmentation & 0.744 & & & \\
\hline Sending electronic catalogue & 0.781 & & & \\
\hline Managing customer database & 0.799 & & & \\
\hline Finding the "right" overseas agent & & 0.691 & & \\
\hline Management of company relationship & & 0.539 & & \\
\hline Awareness, knowledge and orientation & & 0.788 & & \\
\hline
\end{tabular}




\begin{tabular}{|l|l|l|l|l|}
\hline Market selection & & 0.857 & & \\
\hline Respect for and orientation to customers & & 0.738 & & \\
\hline Communications procedures & & 0.658 & & \\
\hline Marketing mix policies & & 0.611 & & \\
\hline New sales & & & 0.770 & \\
\hline Total sales & & & 0.817 & \\
\hline Customer Service & & & 0.829 & \\
\hline Customer Relationships & & & 0.771 & \\
\hline Number of salespeople & & & & 0.816 \\
\hline Salespeople travels time & & & & 0.789 \\
\hline Sales and customer service costs & & & & 0.770 \\
\hline Time reduction of routine service jobs & & & & 0.749 \\
\hline Initial Eigenvalues & 11.089 & 2.350 & 1.479 & 1.272 \\
\hline \% of Variance & 20.257 & 18.350 & 17.780 & 17.208 \\
\hline Cumulative \% & 20.257 & 38.607 & 56.387 & 73.595 \\
\hline
\end{tabular}

The 21 items measuring the effect of the Internet use on marketing activities were subjected to principal component factor analysis. Eigenvalues and scree plot were used to determine the number of factors to be extracted. A four-factor structure was suggested using the criteria of an eigenvalue greater than 1, and the extracted factors account for $73.59 \%$ of the total variance. All factor loadings are generally high, and the lowest loading is equal to 0.567 , while the Kaiser-Meyer-Olkin test of the factor analysis is substantial [0.878]. The resulting factor loadings are shown in table (II) with all factor loadings less than 0.5 suppressed. All items loaded onto the expected factors as they were originally designed. Factor loading were all higher than 0.5 on its own factors and, therefore, each item loaded higher on its associated construct than on any other construct. This supported the discriminant validity of the measurement.

\subsection{Hypotheses Testing}

To test our hypotheses, the data were analysed using path analysis. Path analysis is a multivariate analytical methodology for empirically examining sets of relationships in the form of linear causal models (Duncan, 1986; Li, 1975). The aim of Path analysis is 
to examine the modelled direct and indirect effects of variables hypothesized on the basis of knowledge and theoretical considerations (Pedhazur, 1982). Path analysis does not establish causal relations with certainty, but is used for quantitative interpretations of potential causal relationships (Borchgrevink and Boster, 1998). A path diagram represents the proposed antecedents and consequents among the variables in the model. Arrows are used to symbolize the hypothesized relationships and the direction of the influence in the model. When specifying a path model, a distinction is drawn between exogenous variables and endogenous variables. Exogenous variables influence is outside the model and endogenous variables have influence within the model. In this case, Internet use for marketing is treated as the sole exogenous variable, and marketing activities, targeting activities, and marketing efficiency are the endogenous variables.

The value of the path coefficient associated with each path represents the strength of each linear influence. Structural equation modelling package of AMOS has been used to test the hypotheses developedin the model. Factor scores have been used as single item indicators and performed a path analysis, applying the maximum likelihood estimates (MLE) method, following the guidelines suggested (Joreskog and Sorbom, 1982). To satisfy the analysis criteria, the multivariate normality of the data was investigated by conducting tests of normality, namely skewness, kurtosis, and Mahalanobis distance statistics, (Bagozzi and Yi, 1988). These indicated no departure from normality. So, the analysis proceeded in using MLE method to estimate the model.

The research model-as illustrated in Figure (2)-was run as a structural model and it achieved a good fit of the data (Chi-square $=1.115$, df $=1, \mathrm{P}=0.291 ; \mathrm{CMIN} / \mathrm{DF}=$ 1.115; GFI $=0.966, \mathrm{AGFI}=0.946 ; \mathrm{CFI}=1)$. The chi-square value is very small $(\mathrm{Chi}-$ 
square $=1.115, \mathrm{df}=1, \mathrm{P}=0.291)$ and insignificant $(\mathrm{P}=0.291)$, which reflect a very good of fit. Furthermore, the other goodness-of-fit measures quoted are very good. There is a huge literature on testing the "goodness-of-fit" of SEM solutions. The principal consensus seems to be that there is no consensus on which is the best approach. Bollen and Long (1993) provide probably the best discussion of the many is sues involved. The so-called Goodness-of-Fit Index (GFI) is 0.996, and the Adjusted Goodness-of-Fit Index (AGFI) is 0.946. The best we can get is unity with these two measures. Bentler (1990) revised Normed Fit Index (NFI) to take sample size into account and proposed the Comparative Fit Index (CFI). He suggests that the CFI should be the index of choice when assessing the goodness-of-fit of the model. The CFI for the measurement model is 1, which is greater than the 0.90 benchmark proposed by Bentler (1992). Therefore, on the basis of the results obtained, we would probably say that the model is "good enough".

Figure 2 shows the estimated standardised parameters for the causal paths. Internet Use for marketing activities is positively affects customer relations' activities H1 (Standardised Estimate=0.613, $\mathrm{P}<0.01$ ), marketing performance $\mathbf{H 2}$ (Standardised Estimate $=0.707, \mathrm{P}<0.01$ ), marketing efficiencyH3 (Standardised Estimate=0.169, $\mathrm{P}<$ 0.05) and customer targeting activities $\mathbf{H 4}$ (Standardised Estimate=0.148, $\mathrm{P}<0.05$ ).

With respect to customer relations' activities, it was found that it positively affect marketing performance H5 (Standardised Estimate=0.350 P, 0.05) and marketing efficiency H6 (Standardised Estimate=0.454 P, 0.01). Finally, with respect to customer targeting activities, it was found that it has a positive impact on marketing performance H7, marketing efficiency (Standardised Estimate=0.293 P, 0.01) and H8 (Standardised Estimate $=0.493 \mathrm{P}, 0.01)$. 
Many researchers recommended calculating the overall impact of Internet use on different marketing activities (Bryman and Cramer, 2001). Calculating the direct and indirect effect of each variable would do this. The following table (III) shows direct, indirect and total effects of all variables.

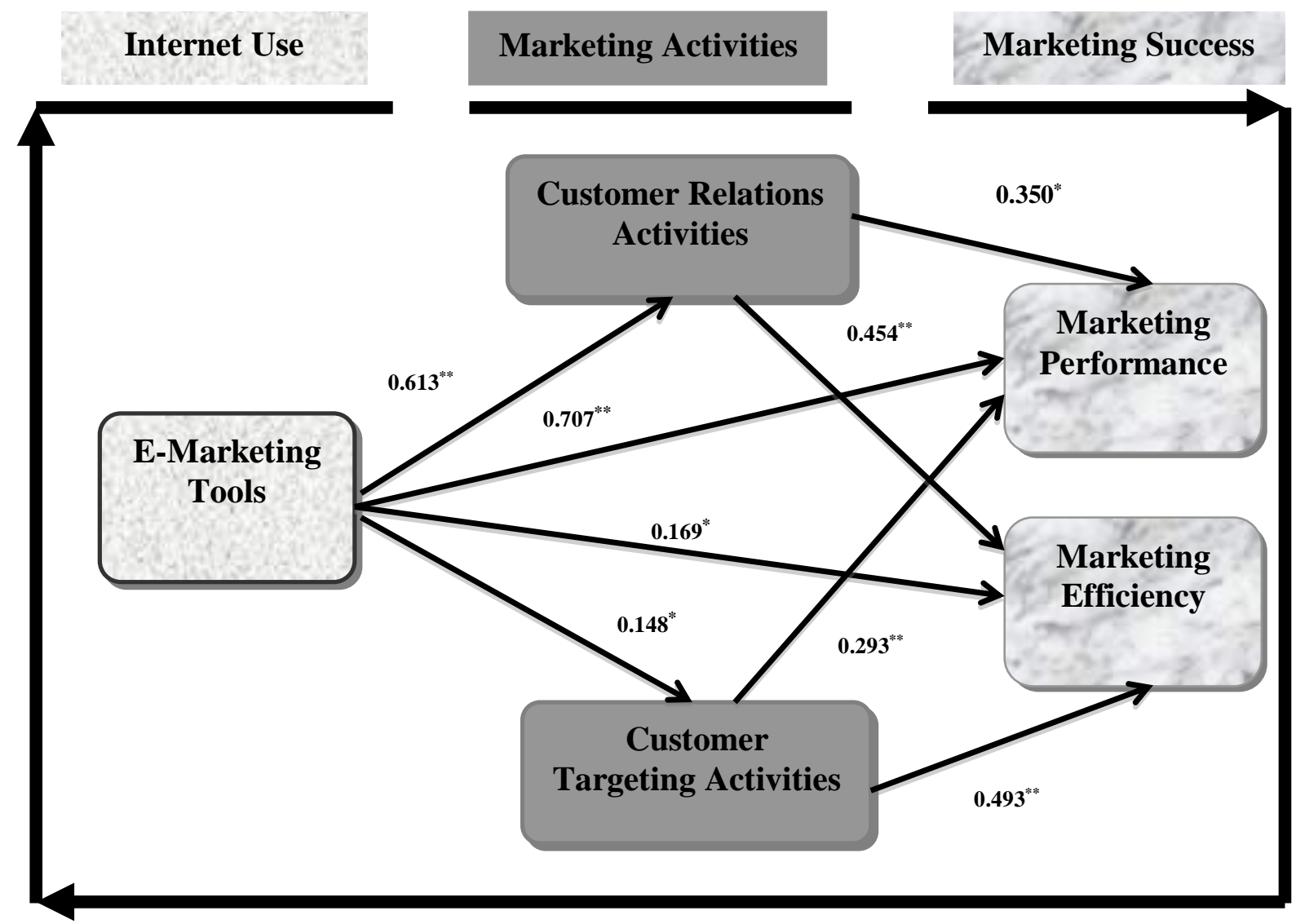

Figure 1: Research Model 
Table III: Direct, Indirect and Total Effect of the Internet Use for B-to-B Marketing

\begin{tabular}{|l|c|c|c|}
\hline \multirow{2}{*}{ Dependent Variables } & \multicolumn{3}{|c|}{ Internet Use for B-to-B IIM } \\
\cline { 2 - 4 } & Direct Effect & Indirect Effect & Total Effect \\
\hline Customer Relations Activities & 0.613 & 0.000 & 0.613 \\
\hline Customer Targeting Activities & 0.148 & 0.000 & 0.148 \\
\hline Marketing performance & 0.707 & 0.214 & 0.921 \\
\hline Marketing Efficiency & 0.169 & 0.072 & 0.241 \\
\hline
\end{tabular}

\section{DISCUSSION}

Generally, our findings support our hypotheses. The results of the questionnaire helped us to understand the effect of using the Internet for marketingactivities. The use of the Internet significantly affects customer relations' activities, marketing performance, marketing efficiency, and customer targeting activities.

In our study, it has been found that the Internet use has a significant positive impact on customer relations' activities. This result is consistent with the theoretical views, which state that the Internet is a facilitator of market-orientated strategies (Deighton, 1996). This finding shows that the Internet facilitates customer relations activities, which, in turn, improve marketing activities (such as respect for/ and orientation to foreign customers, effective marketing mix policies and good awareness, knowledge and orientation), performance (in terms of new sales, total sales, customer service and customer relationships) and marketing efficiency (in terms of decrease in the number of sales force, reduction of salespeople travel time, reduction of sales and customer service costs and time reduction of routine service jobs) .

Regarding customer targeting activities, it was found that these activities are significantly affected by the use of the Internet. These findings support the previous 
researches that stat that the Internet provides numerous advantages for companies wishing to expand their overall potential in targeting final customers. Such as an increase in customer awareness, simplified documentation, access to low cost export market research, improved knowledge of markets, and communication cost savings (Bennett, 1997; Damanpour, 2001; Hamill, 1997; Kotab and Helsen, 2000; Palumbo and Herbig, 1998; Quelch and Klein, 1996; Watson et al, 2000; Wilson and Abel, 2002; Zugelder et al., 2000). Additionally, customer targeting activities were found to affect the marketing efficiency. It appears that the Internet facilitates customer-oriented activities, which, in turn, lead to improved performance. The results of our study further support previous findings that the Internet has attained many objectives for example, speeding up communication between customers and their suppliers, improving service levels, and reducing logistics costs. (Furnell and Karweni, 1999; Honeycutt et al, 1998; Lancioni, et al, 2000; Lord, 2001)

\section{CONCLUSIONS AND IMPLICATIONS}

This study focused on the effects of Internet use on marketing activities. It began by looking at the marketing domain for factors that might be affected by using the Internet for marketing activities. Firstly, to examine the customer relations and targeting implications of the Internet, the study focuses on customer-oriented activities which may be facilitated through the use of the Internet. More specifically, within the spectrum of marketing activities, it examines the issues of finding the "right" agent or distributor, management of company/distributor relationship, customer awareness, market selection, orientation to customers, communication and documentation procedures and marketing 
mix policies. Secondly, the study focuses on those customer relations and targeting activities that may be integrated and enhanced with the interactive attributes of the Internet. Therefore, it examines the issues of discovery of customer needs, customisation of products, new product testing, market segmentation and customer classification, sending electronic catalogue to customers and managing the customer database. Finally, marketing efficiency resulted from cost reduction resulted through the use of the Internet in carrying out marketing activities has been evaluated in this study. This study specify marketing efficiency as reduction in cost of sales, customer service costs, time of routine service jobs, sales people travel time, and number of marketing people employed. The study develops a model of the marketing implications of the Internet. It has validated the model conceptually and empirically

This study provides insight for Internet marketing, its implementation and the linkages between Internet use and marketing efficiency for marketing education and training. The marketing concept and marketing orientation should be stressed since the IS/MIS practitioners and other departmental managers may not have an academic background that supports these new marketing practices. It is necessary, therefore, to have a market-oriented IT/MIS manager in order to make an impact on the success of a company. On the other hand, marketing people should have the required experience and skills to teach other departmental managers how to exploit the market knowledge gained through the use of the new information and communication tool. Otherwise, they will prevent their companies from taking full advantage of the enhanced communication capabilities of the Internet. 
Finally, the findings stress the great role of marketing department and sales force in the successful implementation of the Internet marketing strategies and have some important implications for the marketing people. In the light of the increasing information intensity, the new generation of marketing people should be highly qualified, trained and updated to be able to take full advantage of the Internet capabilities. This also calls for reshaping the recruitment, deployment, motivation, training, evaluation, and compensation standards and policies of the marketing management. 


\section{References}

Anderson, T. (1996). Marketing Products to the Global Desktop, in The Internet Strategy Handbook:Lessons from the New Frontier of Business. Boston,MA, Harvard Business School Press.

Avlonitis, G. J. and Karayanni, D. A. (2000). "The Impact of Internet Use on Business to Business Marketing:Examples from American and European Companies." Industerial Marketing Management, 29 (5): 441-459.

Bennett, R. (1997). "Export Marketing and the Internet :Experience of Web Site Use and Perceptions of Export Barriers among UK Businesses." Industerial Marketing Review, 14 (5): 324-344.

Bondra, J. and Davis, T. (1996). "Marketing's Role in Cross-Functional Information Management" Industrial Marketing Management,25(3): 187-195.

Borders, A. L., Jonston, W. J. and Rigdon, E. E. (2001). "Beyond the Dyad:Electronic Commerce and Network Persipectives in Industerial Marketing Management." Industerial Marketing Management, 30 (2): 199-205.

Chaffey, D., Mayer, R., Johnston, K. and Ellis-Chadwick, F. (2000). Internet Marketing:Strategy, Implementation, and Practice. England, Prentice Hall.

Chan, C. and Swatman, P. M. C. (2000). "From EDI to Internet Commerce:The BHL Steel Experiences." Internet Research:Electronic Networking Applications and Policy, 10 (1): 72-82.

Clarke, I. and Flaherty, T. B. (2003), "Web-based B2B Portals", Industrial Marketing Management, 32 (1): 15-23.

Damanpour, F. (2001). "E-business E-commerce Evolution: Persipective and Strategy." Managerial Finance, 27 (7): 17-33.

De Vaus, D. A. (1991). Surveys in social research. (3rd ed), London, UCL Press.

Deighton, J. (1996). "The Future of Interactive Marketing." Harvard Business Review, 74 (6): 151-162.

Duggan, M. and Devenery, J. (2000). "How to make Internet Marketing Simple." Communication World, 17 (4): 58-61.

Eid, R. and El-Gohary, H. (2013), The Impact of E-Marketing Use on Small Business Enterprises' Marketing: The Case of UK Companies, The Service Industries Journal, 33(1): 31-50.

Eid, R. and Trueman, M. (2004), "Factors affecting the success of business-to-business international Internet marketing (B-to-B IIM): an empirical study of UK companies", Industrial Management \& Data Systems, 104 (1): 16-30.

Evans, J. R. and King, V. E. (1999). "Business-to-Business Marketing and the World Wide Web: Planning, Marketing and Assessing Web Sites" Industrial Marketing Management, 28(4): 343-358.

Even, A., Shankaranarayanan, G. and Berger, P. (2010). "Inequality in the utility of customer data: Implications for data management and usage", Journal of Database Marketing \& Customer Strategy Management,17(1): 19-35

Ellsworth, J. H. and Ellsworth, M. V. (1995). The Internet Business Book. New York, John Wiley. 
Ellsworth, J. H. and Ellsworth, M. V. (1996). Marketing on the Internet-Multimedia strategies for the(WWW). New York, John Wiley.

Furnell, S. M. and Karweni, T. (1999). "Security Implications of Electronic Commerce: A Survey of Consumers and Businesses." Internet Research:Electronic Networking Applications and Policy, 9 (5): 372-382.

Hair, J., Ralph, A. and Ronald, T. (1998). Multivariate Data Analysis. 5th ed, London, Prentice-Hall.

Hamill, J. (1997). "The Internet and International Marketing." International Marketing Review, 14 (5): 300-323.

Hamill, J. and Gregory, K. (1997). "Internet Marketing in the Internationalisation of UK SME's.” Journal of Marketing Management, 13: 9-28.

Hofacker, C. F. (2001). Internet Marketing. 3 ed,New York, John Wiley\&Sons,Inc.

Honeycutt, E. D., Flaherty, T. B. and Benassi, K. (1998). "Marketing Industrial Products on the Internet.” Industerial Marketing Management, 27 (1): 63-72.

Kalakota, R. A. and Whiston, A. B. (1997). Electronic Commerce: A Manager's Guide. Reading MA, Addison -Wesley.

Karayanni, D. A. and Baltas, G. A. (2003), "Web Site Characteristics and Business Performance: Some Evidence from International Business to Business Organisations", Marketing Intelligence \& Planning, 21 (2): 105-114.

Kotab, M. and Helsen, K. (2000). Global Marketing Management. 2ed ed.New York, John Wiley\&Sons.Inc.

Lancioni, R. A., Smith, M. F. and Oliva, T. A. (2000). "The Role of the Internet on the Supply Chain Management.” Industerial Marketing Management, 29 (1): 45-56.

Li, C. C. (1975). Path Analysis: A Primer, Pacific Grove, CA, The Boxwood Press.

Lord, D. (2001), B2B eCommerce:From EDI to eMarketplaces, London, Datamonitor PLC.

Lynn, G. S., Lipp, S. M., Akgun, A. E. and Jr, A. C. (2002). "Factors Impacting the Adoption and Effectiveness of the World Wide Web in Marketing." Industrial Marketing Management, 31 (1): 35-49.

Mang, p. and Stauss, B. (1999). "“Culture Shocks" in Inter-Cultural Service Encounters?" Journal of Service Marketing, 13(4/5): 329-346.

Osterle, H. (2001). Business Networking: Shaping Collaboration Between Enterprises. Berlin Heidelberge, Springer-Verlag.

Palumbo, F. and Herbig, P. (1998). "International Marketing Tool:the Internet." Industrial Management\&Data Systems, 98 (6): 253-261.

Papows, J. (1998). Enterprise.Com, Reading, MA: Perseus Books.

Paul, P. (1996). "Marketing on the Internet.” Journal of Consumer Marketing, 13 (4): 2739.

Peppers, D. and Rogers, M. (1999). Enterprise One to One. New York, Currency/Doubleday.

Poon, S. and Swatman, P. M. C. (1998). "A Combined Method Study of Small Business Internet-Commerce" International journal of Electronic Commerce, 2(3): 31-46.

Quelch, J. A. and Klein, L. R. (1996). "The Internet and International Marketing." Sloan Management Review (Spring): 60-75. 
Rose, S., Hair, N. and Clark, M. (2011). "Online Customer Experience: A Review of the Business-to-Consumer Online Purchase Context" International Journal of Management Reviews, 13 (1): 24-39.

Skinner, S. (1999). Business-to-Business E-Commerce: Investment Perspective. London, Durlacher Ltd.

Soh, C., Mah, Q. Y., Gan, F. J., Chew, D. and Reid, E. (1997). "The Use of the Internet for Business:Experience of Early Adoptors in Singapore." Internet Research:Electronic Networking Applications and Policy, 7 (3): 217-228.

Turban, E., King, D., Lee, J., Warkentin, M. and Chung, H. M. (2002). Electronic Commerce: A Managerial Perspective. New Jersey, Prentice Hall-Pearson Education.

Venkatraman, N. and Henderson, C. (1998). "Real Strategies for Virtual Organizing." Sloan Management Review, 40 (Fall): 33-48.

Watson, R. T., Zinkhan, G. M. and Pitt, L. F. (2000). "Integrated Internet Marketing." Communication of the ACM, 43 (6): 97-102.

Webster, F. (1984). Industrial Marketing Strategy. New York, John Wiley and Sons.

Wilson, S. G. and Abel, I. (2002). "So you want to get involved in E-Commrce." Industerial Marketing Management, 31 (2): 85-94.

Zugelder, M. T., Flaherty, T. B. and Johnson, J. P. (2000). "Legal Issues Associated with International Internt Marketing." International Marketing Review, 17 (3): 253271. 